\title{
Pengembangan Perangkat Pembelajaran Seni Bela Diri Pencak Silat Berbasis Aplikasi Smart Application Creator untuk Guru KKG PJOK Sekolah Dasar Kelas IV
}

\author{
Deby Risma Subekti*, Lokananta Teguh Hari Wiguno, Ari Wibowo Kurniawan \\ Universitas Negeri Malang, Jl. Semarang No. 5 Malang, Jawa Timur, Indonesia \\ *Penulis korespondensi, Surel: debyr12333@gmail.com
}

Paper received: 17-6-2021; revised: 1-7-2021; accepted: 8-7-2021

\begin{abstract}
The purpose of research is to develop a learning tool for self-defense pencak silat based on the Smart Application Creator. This research uses the research model developed by Lee and Owen and adapts several steps from the Borg and Gall model. The stages of this research are: 1) needs analysis, 2) product design, 3) product development and expert justification, 4) implementation (small and large group trials), and 5) product evaluation. The data obtained in this research are quantitative and qualitative data. Both data were obtained from filling out the expert justification questionnaire sheet, small group trials and large group trials. The subjects of this research are teachers of KKG PJOK Elementary Schools in Karangan District, Trenggalek Regency. From the results of the justification of the experts, the media experts obtained 98 percent product worthiness, 85 percent learning experts, 81 percent PJOK experts, 98 percent elementary school game experts, while self-defense pencak silat experts obtained 95 percent product worthiness results. Meanwhile, the results of filling out the questionnaire sheet for small and large group trials by the KKG PJOK elementary school teachers in the trial activities obtained a percentage of 85.9 percent and 88.5 percent. Based on the validity level criteria, it can be concluded that the Smart Application Creator is included in the "very valid" level or worth it for use in the learning process of self-defense pencak silat.
\end{abstract}

Keywords: learning; self-defense pencak silat; smart application creator

\begin{abstract}
Abstrak
Penelitian ini bertujuan untuk mengembangkan perangkat pembelajaran seni bela diri pencak silat berbasis aplikasi Smart Application Creator. Penelitian ini menggunakan model penelitian Lee dan Owen serta mengadaptasi beberapa langkah dari model Borg dan Gall. Tahapan penelitian ini, yaitu: 1) analisis kebutuhan, 2) desain produk, 3) pengembangan produk dan justifikasi ahli, 4) pelaksanaan (uji coba kelompok kecil dan kelompok besar), dan 5) evaluasi produk. Data yang diperoleh pada penelitian ini yaitu data kuantitatif dan data kualitatif. Kedua data tersebut diperoleh dari pengisian lembar angket justifikasi ahli, uji coba kelompok kecil dan uji coba kelompok besar. Subjek pada penelitian ini, yaitu guru KKG PJOK Sekolah Dasar Kecamatan Karangan Kabupaten Trenggalek. Dari hasil justifikasi para ahli, pada ahli media didapatkan hasil kelayakan produk sebesar 98 persen, ahli pembelajaran 85 persen, ahli PJOK 81 persen, ahli permainan SD 98 persen, sedangkan ahli bela diri pencak silat sebesar 95 persen. Sementara itu, hasil pengisian lembar angket uji coba kelompok kecil dan kelompok besar oleh guru KKG PJOK Sekolah Dasar pada kegiatan uji coba diperoleh persentase hasil 85,9 persen dan 88,5 persen. Berdasarkan kriteria tingkat validitas, dapat disimpulkan bahwa aplikasi Smart Application Creator termasuk dalam tingkat "sangat valid" dan layak untuk digunakan dalam proses pembelajaran bela diri pencak silat.
\end{abstract}

Kata kunci: pembelajaran; bela diri pencak silat; smart application creator

\section{Pendahuluan}

Pencak silat dapat diartikan sebagai bela diri asli dari negara Indonesia. Pencak silat merupakan kebudayaan asli yang perkembangannya berjalan beriringan dengan sejarah perkembangan masyarakat Indonesia (Kholis, 2016). Pembelajaran bela diri pencak silat dapat 
memberikan pengaruh positif pada tumbuh kembang anak, sehingga pembelajaran beladiri pencak silat wajib diberikan kepada anak mulai dari jenjang pendidikan Dasar (SD). Pembelajaran bela diri pencak silat untuk siswa sekolah dasar perlu diberikan secara menarik dan inovatif agar pembelajaran yang dilakukan bisa berjalan sesuai tujuan yang diharapkan. Terlebih dalam kondisi virus corona seperti saat ini yang mengharuskan pembelajaran dilakukan secara online/daring, sehingga guru dituntut untuk kreatif dan inovatif dalam pembelajaran. Nuryana, (2020) mengatakan bahwa peralihan pelaksanaan pembelajaran saat ini membuat berbagai pihak harus mampu untuk mengikuti alur sesuai dengan keadaan saat ini agar pembelajaran dapat berjalan maksimal, salah satunya dengan menerapkan media pembelajaran. Penggunaan media pembelajaran dalam kondisi seperti saat ini, sangat penting dilakukan guna mempermudah komunikasi antara guru dengan siswa. Salah satu contoh media pembelajaran yang dapat digunakan yaitu media interaktif yang berupa aplikasi, contohnya aplikasi Smart Application Creator.

Aplikasi Smart Application Creator ini dapat menjadi salah satu alternatif media pembelajaran yang menarik yang dapat dimanfaatkan oleh guru dalam proses pembelajaran. Sebagaimana pendapat Angga dkk., (2020) dalam penelitiannya bahwa pengembangan alat bantu berupa multimedia interaktif pada mata kuliah pencak silat dapat membantu memaksimalkan pemahaman konsep dan meningkatkan kemampuan dalam teknik dasar pencak silat. Pemanfaatan media pembelajaran dalam proses pembelajaran, dapat membantu guru menyampaikan materi dengan mudah kepada siswa, sehingga pembelajaran akan berjalan efektif dan efisien. Guru memiliki peran penting dalam menyampaikan materi bela diri pencak silat kepada siswa, dikarenakan pemberian materi bela diri pencak silat harus menyesuaikan dengan kondisi peserta didik agar tujuan dari pemberian materi ini tercapai.

Menurut Idzhar, (2016) guru menempati posisi yang sangat strategis dalam mengembangkan potensi peserta didik, sehingga perlu adanya pembekalan kemampuan secara profesional untuk guru melaksanakan tugasnya. Oleh sebab itu, perlu adanya wadah yang dapat menaungi guru dalam bertukar pendapat, pikiran, pengalaman serta meningkatkan profesionalitas dalam pembelajaran, contohnya organisasi Kelompok Kerja Guru (KKG). Arsyad \& Sulfemi, (2019) berpendapat bahwa Kelompok Kerja Guru (KKG) adalah sebuah organisasi guru yang bersifat mandiri tanpa ada ikatan hierarkis dari lembaga-lembaga lain. KKG menjadi salah satu wadah bagi guru untuk berdiskusi, tanya jawab dan pembinaan, guna meningkatkan kompetensi dan profesionalitas serta mutu pendidikan agar menjadi lebih baik.

Hasil observasi awal berupa wawancara dengan ketua KKG PJOK SD Kecamatan Karangan yang telah dilakukan oleh peneliti pada hari Senin, 15 Juni 2020, diperoleh hasil yaitu pembelajaran selama pandemi virus corona menggunakan grup whatsapp dengan memberikan instruksi kepada peserta didik untuk mempelajari buku pegangan. Beliau mengatakan bahwa perlu adanya pengembangan perangkat pembelajaran yang bisa diakses kapan saja. Sedangkan hasil kuesioner angket yang disebar kepada Guru KKG PJOK SD Kecamatan Karangan mendapatkan 23 responden dengan hasil $91.3 \%$ guru memberikan materi pencak silat di kelas IV sekolah dasar, 91,3\% guru belum pernah mengembangkan perangkat pembelajaran yang bisa diakses kapan saja, $95.7 \%$ guru belum pernah mengembangkan bahan ajar yang bisa diakses kapan saja, 87\% guru belum pernah mengembangkan evaluasi yang bisa diakses kapan saja, 100\% guru menganggap perlu adanya bahan ajar yang bisa diakses kapan saja, 100\% guru menganggap perlu adanya pengembangan evaluasi yang bisa diakses kapan saja. 
Berdasarkan latar belakang masalah tersebut, peneliti tertarik untuk mengembangkan aplikasi pembelajaran Smart Application Creator sebagai media pembelajaran interaktif yang dapat digunakan oleh guru dalam pembelajaran bela diri pencak silat. Aplikasi Smart Application Creator ini diharapkan dapat menjadi salah satu alternatif media pembelajaran yang inovatif dan menarik digunakan oleh guru dalam proses pembelajaran bela diri pencak silat, sehingga pembelajaran dapat berlangsung secara efektif dan efisien. Selain itu, adanya aplikasi ini diharapkan dapat membantu siswa mempelajari materi bela diri pencak silat dengan mudah, terlebih dalam kondisi pembelajaran daring seperti saat ini. Penelitian dan pengembangan ini merujuk pada hasil penelitian terdahulu yang relevan dengan penelitian ini.

Penelitian yang dilakukan oleh Mashud \& Widiastuti, (2018) mendapatkan hasil bahwa multimedia interaktif lebih efektif digunakan sebagai media pembelajaran renang gaya bebas. Sedangkan penelitian terdahulu yang dilakukan oleh Arwanda dkk., (2020) dengan menggunakan aplikasi Articulate Storyline yang dibuat untuk Peserta Didik Kelas IV Sekolah Dasar Tema 7, didapati hasil dari penelitian ini menunjukkan bahwa pengembangan media pembelajaran berbasis aplikasi Articulate Storyline menggunakan kurikulum 2013 dan berbasis kompetensi peserta didik abad 21 dapat digunakan sebagai pendukung proses pembelajaran dan mendapatkan respon hasil penelitian dengan predikat sangat baik. Serta penelitian terdahulu yang menggunakan aplikasi Smart Application Creator yang dilakukan oleh Jannah didapati hasil penelitian tersebut menunjukkan bahwa dalam penelitian ini mobile learning mempunyai pengaruh pada motivasi belajar peserta didik, sehingga terdapat peningkatan nilai yang didapat peserta didik. Dengan media yang sudah dikembangkan peserta didik lebih bisa belajar secara mandiri di mana saja dan kapan saja. Media ini membantu siswa memahami materi dengan mudah, sehingga nilai yang diperoleh oleh peserta didik mengalami peningkatan dari sebelumnya.

\section{Metode}

Penelitian dan pengembangan ini menggunakan model penelitian yang dikembangkan oleh Lee dan Owen dan mengadaptasi beberapa langkah dari model Borg dan Gall. Tahapan penelitian dan pengembangan ini, yaitu: 1) analisis kebutuhan, 2) desain produk, 3) pengembangan produk dan justifikasi ahli, 4) pelaksanaan (uji coba kelompok kecil dan kelompok besar), dan 5) evaluasi produk. Pada tahap analisis kebutuhan akan dilakukan wawancara kepada ketua KKG serta penyebaran angket analisis uji coba kepada guru anggota KKG. Pada tahap design (perencanaan) peneliti merumuskan gambaran produk dengan membuat alur cerita (Storyboard) serta membuat prosedur pengembangan (flowchart). Berikutnya pada tahap development (pengembangan) peneliti meminta justifikasi ahli dari 5 orang ahli yaitu ahli media, ahli pembelajaran, ahli PJOK, ahli permainan sekolah dasar dan ahli bela diri pencak silat untuk mendapat tanggapan, saran, masukan, serta komentar guna memperbaiki produk awal yang sudah dibuat. Berikutnya tahap implementation (pelaksanaan), yaitu melakukan uji coba produk kepada Guru KKG PJOK SD Kecamatan Karangan dengan 2 tahap yaitu yang pertama uji coba kelompok kecil dengan responden 8 orang guru dan yang kedua adalah uji coba kelompok besar dengan responden 15 orang guru menggunakan angket yang sudah disediakan. Pada tahap evaluasi akan dilakukan pengolahan data hasil penelitian yang digunakan untuk melihat seberapa besar kelayakan produk yang sudah dikembangkan.

Subjek pada penelitian ini adalah 23 guru KKG PJOK SD Kecamatan Karangan. Perolehan data pada penelitian ini berbentuk data kualitatif dan kuantitatif. Data kualitatif didapat dari 
saran serta masukan para ahli serta saran dan masukan yang didapat dari Guru PJOK SD Kecamatan Karangan saat uji coba dilakukan, sedangkan perolehan data kuantitatif akan didapat melalui hasil tinjauan semua ahli dan angket hasil uji coba kelompok kecil dan hasil uji coba kelompok besar yang telah dilaksanakan yang akan terbentuk berupa angka dengan instrumen pengumpulan data berupa pilihan jawaban angket. Teknik analisis data yang dilaksanakan di penelitian ini menggunakan teknik analisis menurut Sugiyono, (2017) Teknik dalam pengukuran ini menggunakan skala likert, yaitu teknik yang digunakan dalam mengukur pendapat, persepsi dan sikap seorang individu serta kumpulan individu yang lain dalam menanggapi fenomena sosial sesuai dengan tujuan pengukuran ini.

\section{Hasil dan Pembahasan}

\subsection{Hasil}

\subsubsection{Hasil Analisis Data Ahli Media}

Penyajian hasil analisis data validasi Ahli Media $(\mathrm{n}=1)$ dengan meninjau dari beberapa aspek yang berbeda disajikan dalam Tabel 1 .

Tabel 1. Hasil Analisis Data Ahli Media

\begin{tabular}{clcl}
\hline No & \multicolumn{1}{c}{ Aspek } & Kriteria & Keterangan \\
\hline 1. & Kejelasan & 95 & Sangat Valid \\
2. & Kelengkapan & 100 & Sangat Valid \\
3. & Kemudahan & 100 & Sangat Valid \\
4. & Kemenarikan & 100 & Sangat Valid \\
5. & Kesesuaian & 98 & Sangat Valid \\
6. & Ketepatan & 100 & Sangat Valid \\
\hline \multicolumn{2}{l}{ Rata-rata } & 99 & Sangat Valid \\
\hline
\end{tabular}

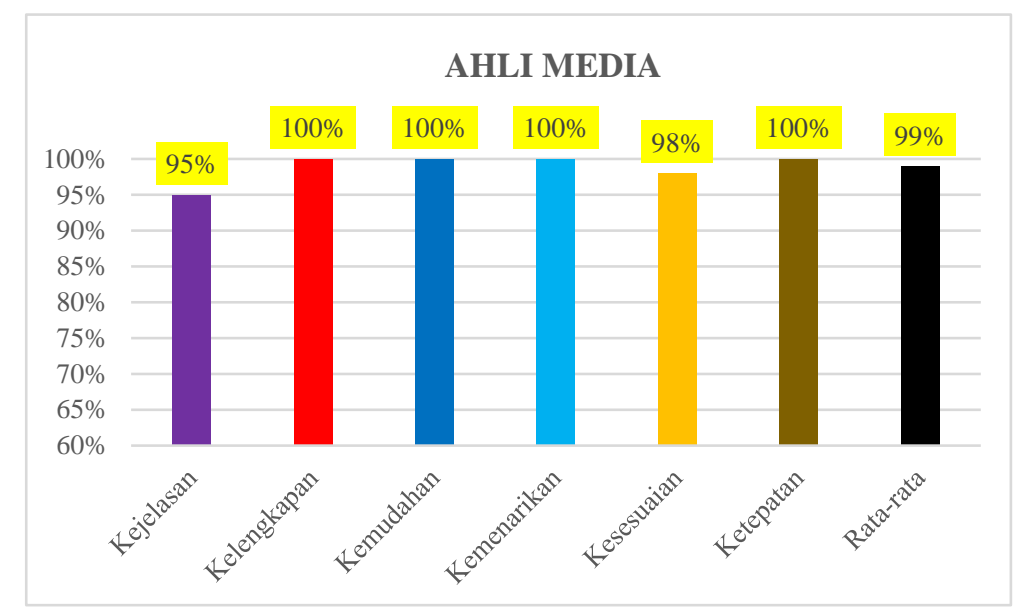

Gambar 1. Diagram Persentase Hasil Analisis Data Ahli Media

Dari hasil analisis data ahli media yang sudah dilakukan mendapatkan persentase sebesar 99\% dengan kategori sangat valid, sehingga produk pengembangan yang berjudul "Pengembangan Perangkat Pembelajaran Seni Bela Diri Pencak Silat Berbasis Aplikasi Smart Application Creator untuk Guru KKG PJOK SD di Kecamatan Karangan Kabupaten Trenggalek" 
layak digunakan dan diterapkan kepada peserta didik agar pembelajaran menjadi lebih inovatif dan menarik.

\subsubsection{Hasil Analisis Data Ahli Pembelajaran}

Penyajian hasil analisis data Ahli Pembelajaran $(\mathrm{n}=1)$ dengan meninjau dari beberapa aspek yang berbeda disajikan dalam Tabel 2 .

Tabel 2. Hasil Analisis Data Ahli Pembelajaran

\begin{tabular}{cccl}
\hline No & Aspek & Kriteria & Keterangan \\
\hline 1. & Kejelasan & 83 & Sangat Valid \\
2. & Ketepatan & 86 & Sangat Valid \\
3. & Kemudahan & 85 & Sangat Valid \\
\hline \multicolumn{2}{l}{ Rata-rata } & 85 & Sangat Valid \\
\hline
\end{tabular}

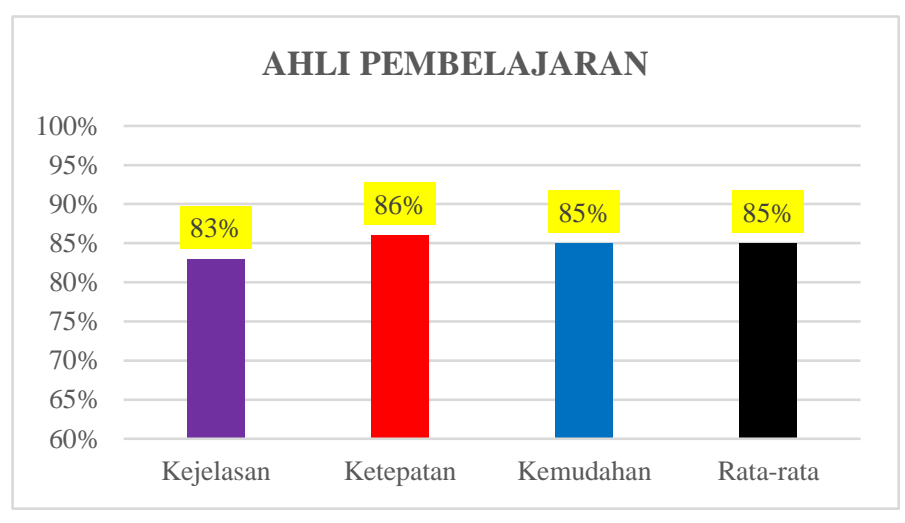

Gambar 2. Diagram Persentase Hasil Analisis Data Ahli Pembelajaran

Dari hasil analisis data ahli pembelajaran yang sudah dilakukan mendapatkan persentase sebesar $85 \%$ dengan kategori sangat valid sehingga produk pengembangan yang berjudul "Pengembangan Perangkat Pembelajaran Seni Bela Diri Pencak Silat Berbasis Aplikasi Smart Application Creator untuk Guru KKG PJOK SD di Kecamatan Karangan Kabupaten Trenggalek" layak digunakan dan diterapkan kepada peserta didik agar pembelajaran menjadi lebih inovatif dan menarik.

\subsubsection{Hasil Analisis Data Ahli PJOK}

Penyajian hasil analisis data Ahli PJOK $(\mathrm{n}=1)$ dengan meninjau dari beberapa aspek yang berbeda disajikan dalam Tabel 3 .

Tabel 3 Hasil Analisis Data Ahli PJOK

\begin{tabular}{clcl}
\hline No & \multicolumn{1}{c}{ Aspek } & Kriteria & Keterangan \\
\hline 1. & Kejelasan & 79 & Sangat Valid \\
2. & Ketepatan & 88 & Sangat Valid \\
3. & Kemudahan & 79 & Sangat Valid \\
4. & Kemenarikan & 83 & Sangat Valid \\
5. & Kesesuaian & 75 & Sangat Valid \\
\hline \multicolumn{2}{l}{ Rata-rata } & 81 & Sangat Valid \\
\hline
\end{tabular}




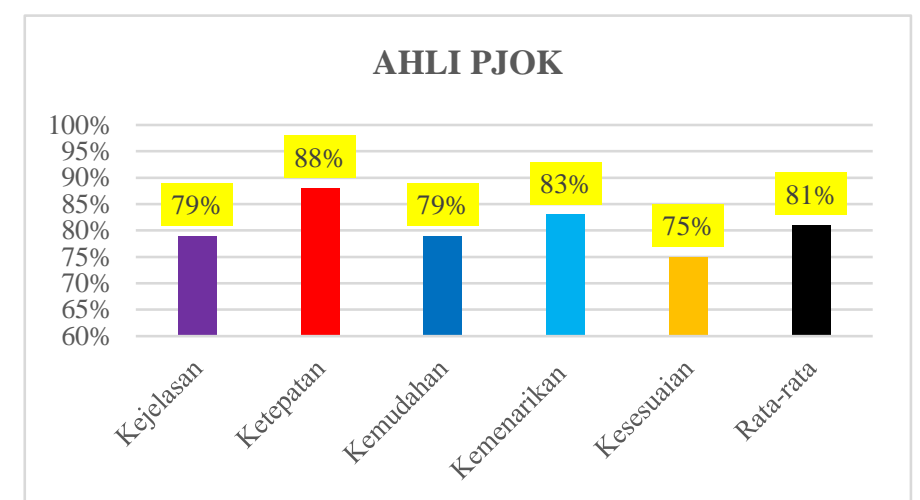

\section{Gambar 3. Diagram Persentase Hasil Analisis Data Ahli PJOK}

Dari hasil analisis data ahli PJOK yang sudah dilakukan mendapatkan persentase sebesar 81\% dengan kategori sangat valid sehingga produk pengembangan yang berjudul "Pengembangan Perangkat Pembelajaran Seni Bela Diri Pencak Silat Berbasis Aplikasi Smart Application Creator untuk Guru KKG PJOK SD di Kecamatan Karangan Kabupaten Trenggalek" layak digunakan dan diterapkan kepada peserta didik agar pembelajaran menjadi lebih inovatif dan menarik.

\subsubsection{Hasil Analisis Data Ahli Permainan Sekolah Dasar}

Penyajian hasil analisis data Ahli Permainan Sekolah Dasar $(n=1)$ dengan meninjau dari beberapa aspek yang berbeda disajikan dalam Tabel 4 .

Tabel 4. Hasil Analisis Data Ahli Permainan Sekolah Dasar

\begin{tabular}{clcl}
\hline No & \multicolumn{1}{c}{ Aspek } & Kriteria & Keterangan \\
\hline 1. & Kejelasan & 100 & Sangat Valid \\
2. & Ketepatan & 100 & Sangat Valid \\
3. & Kemudahan & 96 & Sangat Valid \\
4. & Kemenarikan & 88 & Sangat Valid \\
5. & Kesesuaian & 100 & Sangat Valid \\
\hline \multicolumn{2}{l}{ Rata-rata } & 97 & Sangat Valid \\
\hline
\end{tabular}

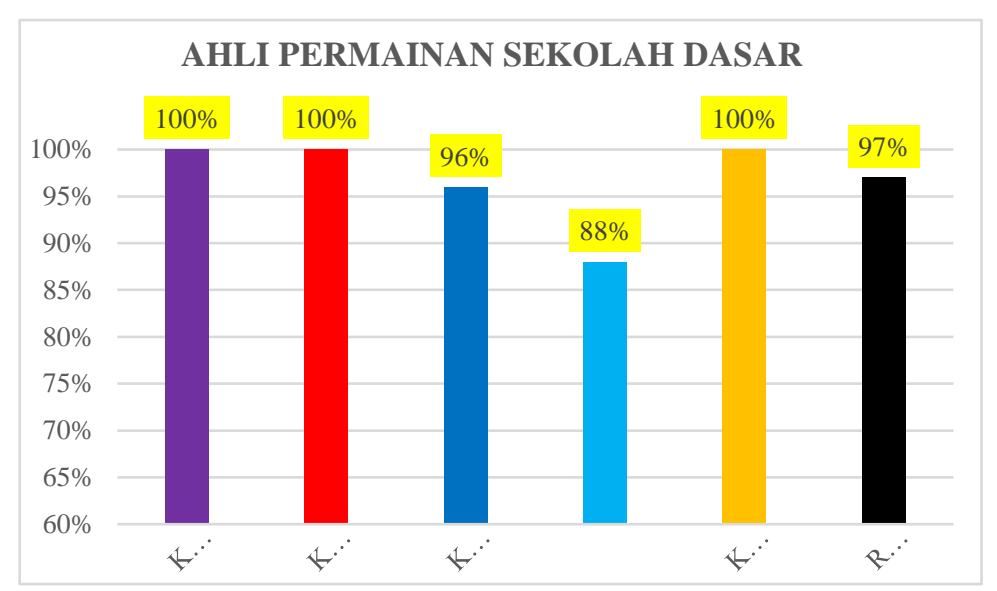

Gambar 4. Diagram Persentase Hasil Analisis Data Ahli Permainan Sekolah Dasar 
Dari hasil analisis data ahli Permainan Sekolah Dasar yang sudah dilakukan mendapatkan persentase sebesar $97 \%$ dengan kategori sangat valid, sehingga produk pengembangan yang berjudul "Pengembangan Perangkat Pembelajaran Seni Bela Diri Pencak Silat Berbasis Aplikasi Smart Application Creator untuk Guru KKG PJOK SD di Kecamatan Karangan Kabupaten Trenggalek" layak digunakan dan diterapkan kepada peserta didik agar pembelajaran menjadi lebih inovatif dan menarik.

\subsubsection{Hasil Analisis Data Ahli Bela Diri Pencak Silat}

Penyajian hasil analisis data Ahli Bela Diri Pencak Silat $(n=1)$ dengan meninjau dari beberapa aspek yang berbeda disajikan dalam Tabel 5 di bawah ini:

Tabel 5. Hasil Analisis Data Ahli Bela Diri Pencak Silat

\begin{tabular}{clcl}
\hline No & \multicolumn{1}{c}{ Aspek } & Kriteria & Keterangan \\
\hline 1. & Kejelasan & 100 & Sangat Valid \\
2. & Ketepatan & 96 & Sangat Valid \\
3. & Kemudahan & 88 & Sangat Valid \\
4. & Kemenarikan & 100 & Sangat Valid \\
5. & Kesesuaian & 92 & Sangat Valid \\
\hline Rata-rata & 95 & Sangat Valid \\
\hline
\end{tabular}

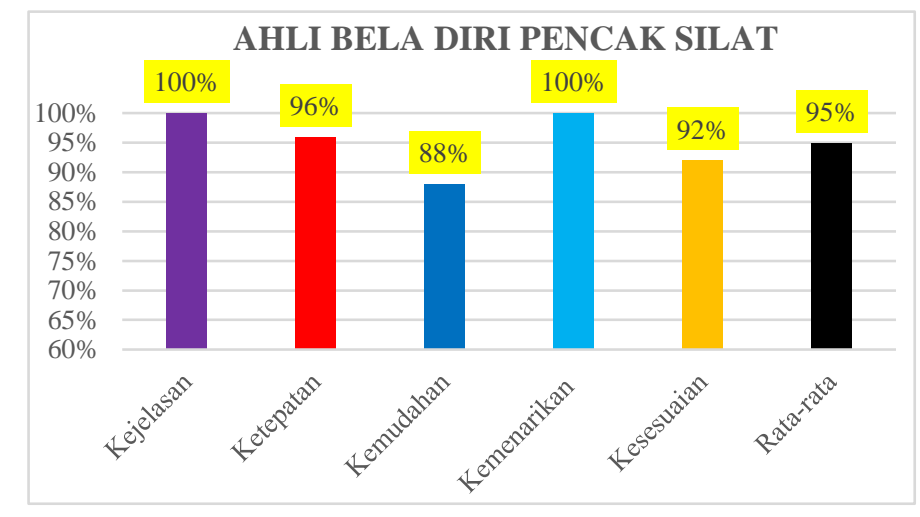

\section{Gambar 5. Diagram Persentase Hasil Analisis Data Ahli Bela Diri Pencak Silat}

Dari hasil analisis data ahli Bela Diri Pencak Silat yang sudah dilakukan mendapatkan persentase yaitu 95\% yang berarti kategori sangat valid, dapat disimpulkan bahwa produk pengembangan yang berjudul "Pengembangan Perangkat Pembelajaran Seni Bela Diri Pencak Silat Berbasis Aplikasi Smart Application Creator untuk Guru KKG PJOK SD di Kecamatan Karangan Kabupaten Trenggalek" layak digunakan dan diterapkan ke peserta didik agar pembelajaran bertambah inovatif serta menarik.

\subsubsection{Hasil Analisis Data Uji Coba Kelompok Kecil}

Penyajian hasil data analisis data Uji Coba Kelompok Kecil $(n=8)$ dengan meninjau dari beberapa aspek yang berbeda disajikan dalam Tabel 6 . 
Tabel 6. Hasil Analisis Data Uji Coba Kelompok Kecil

\begin{tabular}{clcl}
\hline No & \multicolumn{1}{c}{ Aspek } & Kriteria & Keterangan \\
\hline 1. & Kejelasan & 84 & Sangat Valid \\
2. & Kemenarikan & 89 & Sangat Valid \\
3. & Kemudahan & 84 & Sangat Valid \\
4. & Kegunaan & 91 & Sangat Valid \\
5. & Kesesuaian & 84 & Sangat Valid \\
\hline \multicolumn{2}{l}{ Rata-rata } & 86 & Sangat Valid \\
\hline
\end{tabular}

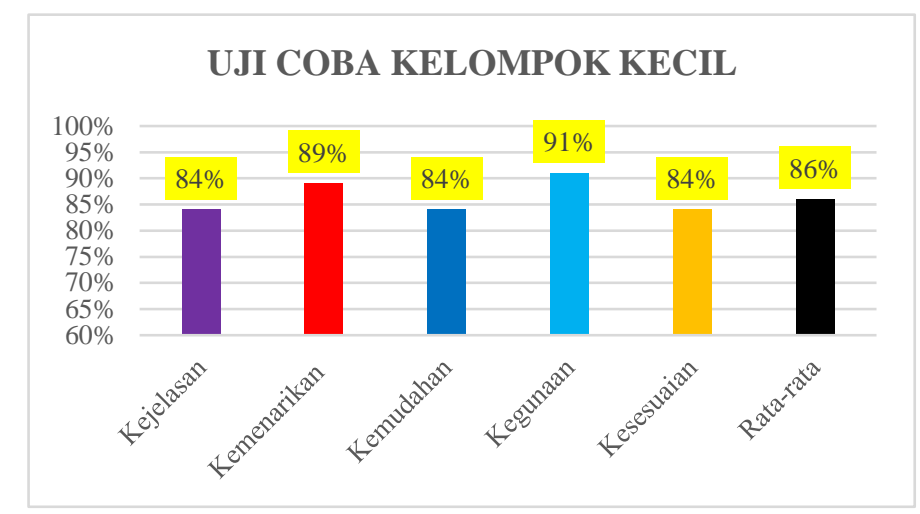

\section{Gambar 6. Diagram Persentase Hasil Data Analisis Data Uji Coba Kelompok Kecil}

Dari hasil data analisis data uji coba kelompok kecil yang sudah dilaksanakan mendapatkan persentase sebesar $86 \%$ dengan kategori sangat valid, sehingga produk pengembangan yang berjudul "Pengembangan Perangkat Pembelajaran Seni Bela Diri Pencak Silat Berbasis Aplikasi Smart Application Creator untuk Guru KKG PJOK SD di Kecamatan Karangan Kabupaten Trenggalek" layak digunakan oleh guru KKG PJOK SD Kecamatan Karangan dan diterapkan terhadap peserta didik agar pembelajaran bertambah inovatif serta menarik.

\subsubsection{Hasil Analisis Data Uji Coba Kelompok Besar}

Penyajian hasil data analisis data Uji Coba Kelompok Besar $(\mathrm{n}=15)$ dengan meninjau dari beberapa aspek yang berbeda disajikan dalam Tabel 7.

Tabel 7. Hasil Analisis Data Uji Coba Kelompok Besar

\begin{tabular}{clcl}
\hline No & \multicolumn{1}{c}{ Aspek } & Kriteria & Keterangan \\
\hline 1. & Kejelasan & 89 & Sangat Valid \\
2. & Kemenarikan & 90 & Sangat Valid \\
3. & Kemudahan & 86 & Sangat Valid \\
4. & Kegunaan & 91 & Sangat Valid \\
5. & Kesesuaian & 87 & Sangat Valid \\
\hline \multicolumn{2}{l}{ Rata-rata } & 89 & Sangat Valid \\
\hline
\end{tabular}




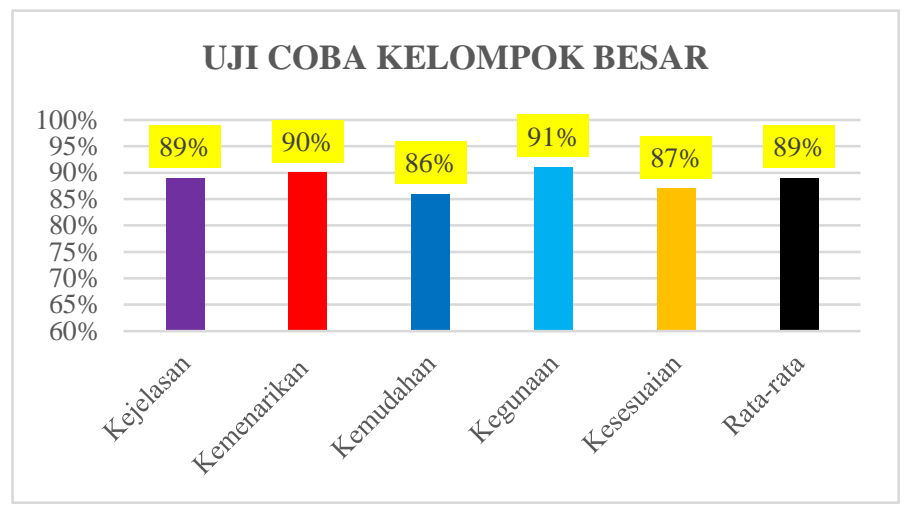

\section{Gambar 7. Diagram Persentase Hasil Data Analisis Data Uji Coba Kelompok Besar}

Dari hasil data analisis data uji coba kelompok besar yang sudah dilaksanakan mendapatkan persentase sebesar $89 \%$ dengan kategori sangat valid, sehingga produk pengembangan yang berjudul "Pengembangan Perangkat Pembelajaran Seni Bela Diri Pencak Silat Berbasis Aplikasi Smart Application Creator untuk Guru KKG PJOK SD di Kecamatan Karangan Kabupaten Trenggalek" layak digunakan oleh guru KKG PJOK SD Kecamatan Karangan dan diterapkan kepada peserta didik agar pembelajaran menjadi lebih inovatif dan menarik.

\subsection{Pembahasan}

Hasil dari pengembangan produk perangkat pembelajaran bela diri pencak silat berbasis aplikasi Smart Application Creator ini secara umum dapat disimpulkan bahwa produk ini layak digunakan untuk Guru KKG PJOK SD Kecamatan Karangan Kabupaten Trenggalek dalam proses belajar pembelajaran. Menurut Pane \& Dasopang, (2017) Pembelajaran ini dapat dikatakan sebagai kegiatan atau proses membimbing serta membantu peserta didik dalam proses pembelajaran. Pembelajaran juga bagian dari pendidikan yang bertujuan untuk memfasilitasi aktivitas belajar seseorang guna meningkatkan kemampuan afektif, kognitif, dan keterampilan (Anggraini dkk., 2014). Dalam pembelajaran terdapat materi bela diri salah satunya ialah bela diri pencak silat, pencak silat ini adalah bela diri warisan nenek moyang bangsa Indonesia. Menurut Islamiyah, (2021) Pencak silat merupakan bagian dari warisan budaya asli bangsa Indonesia. Tidak sedikit dari penduduk Indonesia yang mempelajari bela diri pencak silat. Pencak silat menjadi olahraga yang diminati karena pencak silat sudah dipertandingkan di kancah Internasional. Di dalam pencak silat terdapat gerak dasar yang mencerminkan gerakan membela diri. Gerak dasar pencak silat adalah suatu gerakan terencana, terarah, terkoordinasi, dan terkendali yang mempunyai empat aspek sebagai satu kesatuan yakni aspek mental spiritual, aspek bela diri, aspek olahraga, dan aspek seni budaya (Akbar \& Hariyanto, 2020). Sedangkan menurut Roji \& Yulianti, (2017) Pencak silat membutuhkan tingkat konsentrasi yang tinggi di dalamnya, serta pencak silat ini mempunyai pengaruh dari budaya Cina, agama Budha, agama Hindu serta islam dan tersebar di seluruh nusantara, sehingga setiap daerah mempunyai ciri khas masing-masing. Pencak silat harus diberikan kepada peserta didik agar peserta didik dapat melestarikan bela diri asli Indonesia ini.

Produk pengembangan yang dihasilkan pada penelitian dan pengembangan ini adalah sebuah produk pengembangan perangkat pembelajaran seni bela diri pencak silat berbasis 
aplikasi Smart Application Creator yang terdiri dari beberapa aspek yaitu teks, video, grafik dan suara. Pembelajaran dengan menggunakan media pembelajaran memiliki tujuan supaya memudahkan guru dalam kegiatan penyampaian materi kepada peserta didik, dengan begitu mampu memperoleh tujuan yang sudah ditetapkan. Saodah dkk., (2020) Media merupakan alat perantara yang digunakan media tersebut akan sangat membantu keefektifan proses pembelajaran dan penyampaian isi pesan dan materi pelajaran oleh guru pada saat itu. Pengembangan bahan ajar multimedia interaktif mata kuliah pencak silat dapat membantu meningkatkan pemahaman konsep dan meningkatkan keterampilan teknik dasar pencak silat (Mashud \& Widiastuti, 2018).

Aplikasi ini ialah aplikasi yang bisa diakses kapan saja serta di mana saja. Selain itu, pada aplikasi ini memuat fitur-fitur yang dapat membantu dalam memahami materi. Menurut Suryaningtyas dkk., (2019) Smart Application Creator 3.0 atau disingkat SAC adalah sebuah perangkat lunak yang berguna sebagai alat untuk membuat konten multimedia yang ditentukan untuk perangkat seluler. SAC ini sendiri merupakan media interaktif digital dengan menggunakan fitur-fitur untuk menghasilkan aplikasi UI yang intuitif, interaktivitas, dan perancangan. Aplikasi SAC ini dapat kompatibel dengan sistem operasi iOS dan Android.

Selain itu, pada produk aplikasi pembelajaran berbasis aplikasi Smart Application Creator bela diri pencak silat ini berisi RPP, materi sejarah, sarana dan prasarana, teknik dasar, video, evaluasi pembelajaran dan biodata peneliti. Oleh sebab itu, perangkat pembelajaran Smart Application Creator termasuk ke dalam salah satu media yang menarik dan dapat membantu siswa dalam memahami pembelajaran dengan mudah. Sebagaimana penelitian yang dilakukan oleh Jannah dalam penelitiannya yang menggunakan aplikasi yang sama yaitu Smart Application Creator mendapatkan hasil bahwa mobile learning sangat berpengaruh terhadap motivasi belajar peserta didik, sehingga terdapat peningkatan nilai yang didapat peserta didik. Adanya media ini membantu peserta didik lebih bisa belajar secara mandiri di mana dan kapan saja. Media ini membantu siswa memahami materi dengan mudah, sehingga nilai yang diperoleh oleh peserta didik mengalami peningkatan dari sebelumnya.

Diharapkan dalam pembelajaran bela diri pencak silat lebih bervariasi, sehingga menarik dan dapat meningkatkan minat peserta didik serta menjadi referensi guru dalam pembelajaran Pendidikan Jasmani, olahraga dan kesehatan.

\section{Simpulan}

Penelitian yang sudah dilaksanakan menunjukkan hasil pengembangan produk perangkat pembelajaran bela diri pencak silat berbasis aplikasi Smart Application Creator ini, secara umum dapat disimpulkan produk ini layak digunakan untuk Guru KKG PJOK SD Kecamatan Karangan Kabupaten Trenggalek dalam proses pembelajaran. Namun, sebaiknya dalam penggunaan perangkat pembelajaran berbasis aplikasi ini harus memperhatikan sasaran dan kemampuan dari peserta didik serta memberikan pendampingan dalam proses pembelajaran.

\section{Daftar Rujukan}

Akbar, R. A., \& Hariyanto, E. (2020). Pengembangan Bahan Ajar Pencak silat Untuk Siswa Sekolah Dasar. Sport Science and Health, 2(7), 350-356. http://journal2.um.ac.id/index.php/jfik/index

Angga, P. D., Hariyanto, E., \& Tomi, A. (2020). Pengembangan Bahan Ajar Multimedia Interaktif Pencak Silat Berbasis CourseLab 2.4. Jurnal Pendidikan Jasmani Indonesia, 16(1). 
Anggraini, N. D., Winarno, \& Sulistyorini. (2014). Pengembangan Pembelajaran Teknik Dasar Service Bawah Bolavoli Untuk Siswa Kelas Viii Smp Negeri 5 Malang. Jurnal Olahraga Pendidikan, 1(1), 81-87.

Arsyad, \& Sulfemi, W. B. (2019). Pengaruh Kelompok Kerja Guru (KKG) Terhadap Peningkatan Kompetensi Pedagogik dan Kemampuan Menulis Karya Ilmiah. Jurnal Pendidikan Dasar Indonesia, 4(2), 53-58.

Arwanda, P., Irianto, S., \& Andriani, A. (2020). Pengembangan Media Pembelajaran Articulate Storyline K13 Berbasis Kompetensi Peserta Didik Abad 21. Jurnal Ilmiah Pendidikan Madrasah Ibtidaiyah, 4(2). https://doi.org/10.35931/am.v4i2.331

Idzhar, A. (2016). Peranan Guru Dalam Meningkatkan Motivasi Belajar Siswa. DIDAKTIKA: Jurnal Kependidikan, 2(2), 221-228. https://doi.org/10.30863/didaktika.v12i2.181

Islamiyah, R. (2021). Pengembangan Bahan Ajar Pencak Silat untuk Materi Seni Jurus Tunggal Bagi Ekstrakurikuler. Sport Science and Health, 3(1), 1-7.

Kholis, N. (2016). Aplikasi Nilai-Nilai Luhur Pencak Silat Sarana Membentuk Moralitas Bangsa. Jurnal SPORTIF : Jurnal Penelitian Pembelajaran, 2(2), 76. https://doi.org/10.29407/js_unpgri.v2i2.508

Mashud, \& Widiastuti. (2018). Pengembangan Pembelajaran Renang Gaya Bebas Berbasis Multimedia Interaktif. Jurnal Ilmu Keolahragaan, 9(2). https://doi.org/10.21009/gjik.092.05

Nuryana, A. N. (2020). Dampak Pandemi Covid-19 Terhadap Dunia Pendidikan. Kabar Priangan. https://kabarpriangan.com/dampak-pandemi-covid-19-terhadap-dunia-pendidikan/

Pane, A., \& Dasopang, M. D. (2017). Belajar Dan Pembelajaran. Jurnal Kajian Ilmu-ilmu Keislaman, 3(2), 333351. https://doi.org/10.24952/fitrah.v3i2.945

Roji, \& Yulianti, E. (2017). Pendidikan Jasmani, Olahraga dan Kesehatan. Pusat Kurikulum dan Perbukuan, Balitbang, Kemendikbud.

Saodah, Pratiwi, A. R., Pratiwi, S. A., \& Halimah, S. (2020). Pengunaan Media dalam Pembelajaran PKn SD. Jurnal Pendidikan dan Dakwah, 2(3), 386-395.

Sugiyono. (2017). Metode Penelitian Pendidikan. Bandung: Alfabeta.

Suryaningtyas, V. W., Nugroho, R. A., Cahyono, S. P., Nababan, M. R., \& Santosa, R. (2019). Translation Learning Enrichment Using Smart Application Creator 3.0: An Attempt to Design a Mobile Application in Translation for Tourism Purpose Course. International Seminar on Application for Technology of Information and Communication (ISemantic), 542-547. 